\title{
Rationality Application of "Wisata Barokah" as a Religious Education Strategy in Pandemic
}

\section{(SDIT Al-Ikhlas Mantren Case Study)}

\author{
Yusril Indra Wardana, ${ }^{1, *}$ Agus Machfud Fauzi ${ }^{2}$ \\ ${ }^{1}$ Universitas Negeri Surabaya \\ ${ }^{2}$ Universitas Negeri Surabaya \\ *Corresponding Author. Email: yusril.18034@mhs.unesa.ac.id
}

\begin{abstract}
The covid-19 pandemic has affected various sectors including education and religion. Learning in formal schools that is carried out face-to-face must now change to distance learning. Many parties are pro and contra with this policy because in practice many things have happened. This obstacle is trying to overcome by SDIT AL-IKHLAS by implementing a policy of "wisata barokah". The purpose of this study is to analyze "wisata barokah" which is the strategy of SDIT-AL IKHLAS teachers to continue to carry out religious education during the pandemic. Researchers used a qualitative approach with case studies. The data collection technique used interviews and observations. The data analysis in this research is descriptive qualitative by providing an explanation of the situation under study and study using Max Weber's theory of social action. The result of this research is "wisata barokah" is a strategy taken by the school because this strategy can accommodate the wishes of all parties because they still get religious material well even in a pandemic situation. Apart from that, from Max Weber's theory of social action analysis, this strategy is based on affective action, instrumental rationality, and value rationality.
\end{abstract}

Keywords: Strategy, Religious Education, Social Action, Wisata Barokah

\section{INTRODUCTION}

The beginning of 2020 became the starting point for the emergence of the Covid-19 pandemic in the world, and in March 2020 the virus began to enter Indonesia. Following up on this, the government continues to make various efforts both measures and prevention so that this virus does not spread more rapidly. Starting from the existence of large-scale social restriction policies (PSBB), lockdown, and so on. But it turns out that these efforts are not enough to be able to stop the rate of spread of this virus. The increasingly uncontrolled spread makes the concerns of many parties and many sectors become affected including education, both formal and non-formal. With these impacts, the government as a stakeholder to make policies so that people can still move normally even though they are still in a pandemic situation, from this comes the idea of a new normal or new normal that allows people to move normally but by applying health protocols strictly, this policy gets a lot of positive response from the community.[1], [2]

In the education sector, given that health protocols must be strictly implemented, governments think more deeply about determining education policies in the midst of a pandemic, whether it is better for learners to stick to distance learning or return to school to do face-to-face learning. After going through various studies and considerations, the strategy taken is to continue to carry out distance learning (PJJ) with the consideration that if implemented face-to-face in schools will potentially 
cause crowds that are the most dominant factor in the spread of this virus, in addition this policy is also based on the Circular Letter of the Minister of Education and Health Number 3 of 2020 on the prevention of Covid in the Education Unit on March 9, 2020, Circular Letter of the Minister of Health No. HK.02.01/MENKES/199/2020 on March 12, 2020, and Circular Letter of the Secretary General of the Ministry of Education No.36603/A. A5/OT/2020 on March 15, 2020.

The existence of this distance learning policy is also an effort to prevent the spread of the Covid-19 virus in the school environment. In practice, this policy was initially responded positively by the community, especially parents because he thought this strategy was the safest for the health and safety of their children. But over time began to appear obstacles in the implementation of distance learning like this, ranging from networks, data packages, $\mathrm{hp}$ and obstacles experienced by parents who must be a substitute for teachers in teaching at home for their children who have difficulty understanding the lessons given. Many parents complain about this because they also have other responsibilities such as making a living and taking care of the household. On the other hand, teachers also complain because many learners have difficulty in understanding the material delivered so that it also has an impact on their achievements in school. From there came a lot of input to the school to create an alternative new education strategy that can overcome the problems that arise as a result of distance learning.

Previous relevant research on outdoor religious learning strategies or the impact of learning on children and parents in pandemic times has been studied by several researchers. The first previous research was an article with the title "Implementation of Outdoor Learning in Muhammadiyah 16 Surabaya Elementary School Creative School". The results of this study are: 1) Outdoor learning planning includes setting goals, strategies, resources and determining each outdoor decision that refers to the syllabus and Learning Implementation Plan 2) The implementation of outdoor learning (Outdoor learning) includes the stage of preparation, implementation, and evaluation after activities 3) The supporting factors and obstacles to outdoor learning (Outdoor learning) there are two interen and external sides such as ability of resources, materials, weather transportation conditions [3]

The second previous research was in the Journal of Islamic Education Management with the title "School Leadership in Covid-19 Crisis Situations" explained that in the Before the Crisis stage, it was carried out by carrying out Covid-19 Prevention Literacy. Then at the During the Crisis stage, do (a) Health Talk, (b) Learn from Home Policy, and (c) Video and Podcast Challenge. Lastly, After the Crisis, in a time when schools are being held accountable at the highest levels of standards, strong leadership is essential to school success. Successful schools in research consistently demonstrate strong aspects in effective school leadership. Crisis management is needed so that schools can be better prepared to deal with crises and reduce their impact so that the learning process and activities can run more optimally [4]

The third previous study was in the Journal of Education, Psychology, and Counseling under the title "Exploratory Study of the Impact of the COVID-19 Pandemic on the Online Learning Process in Elementary Schools" which aims to identify and obtain information on the constraints of the online teaching and learning process at home as a result of the pandemic. This research uses exploratory case study methods and qualitative research approaches. This study used informants as many as 6 teachers and parents of students at one of the elementary schools in Tangerang. The result of this study is that there are several obstacles experienced by teachers, students, and parents in the online teaching and learning process, namely the mastery of technology that is still lacking, the cost of increasing due to quotas, the existence of additional parental work because they have to accompany children to learn, communication and socialization between students becomes reduced so as to make students become lazy at home, The burden of teachers and parents is growing because working hours become unlimited because at all times it is required to remain able to communicate[5]

The fourth previous research was in the Journal of Research Proceedings \& Community Service with the title "Optimizing the Role of Parental Supervision in the Implementation of Online Schools In the Covid-19 Pandemic" which aims to identify the implementation of the distance learning process with online school methods. The method used is qualitatively deskritptive by describing and explaining thoroughly and specifically about the current phenomenon, so that the goals of online schools can be achieved optimally. The result of his research is that in practice, the concept of online schools brings many obstacles and significant impacts for learners as well as teachers. The lack of adequate supporting facilities and limited understanding of the understanding of technology and internet networks are obstacles faced by both parties. In addition, another 
problem is that parental supervision and attention to children in online learning is important for the realization of optimal learning outcomes. Parents should be present to supervise and pay attention to the child both before, during, until after the learning takes place [6]

The last previous study was an article entitled "Analysis of Social Action of Max Weber in the Reading of The Book of Mukhtasar Al-Bukhari". The results of this study are: First, based on traditional types of actions, the perpetrators of tradition (Ponpes At-taqwa) want to preserve the traditions that have been carried out for generations by ponpes Sunni Salafiyyah Pasuruan East Java. Second, affective action, shows that the perpetrator has an emotional bond to the character (salafu as-shalih) and the time of implementation (Month of Rajab). Third, instrumental rationality, Ponpes At-Taqwa is consciously able to carry out the tradition because it has the capacity, both in terms of human resources and financial aspects. Fourth, the rationality of values, they want to get barokah by imitating and preserving the traditions of the scholars salafus as-shalih [7]

The five previous studies above show some results related to the research that will be studied in this study. But the five studies above still have no mention of the specifics related to the analysis of educational strategies which in this case is referred to as "wisata barokah" reviewed from the theory of social action Max Weber, besides that what makes this research interesting is this is an update of previous researches because there are differences in informants, times, research locations, and this activity is an innovation of new strategies applied in this school.

\section{METHODS}

This research uses a type of qualitative approach with case studies. Qualitative research method is a research method based on the philosophy of postpositivism, which isused to examine the natural object conditions that researchers are a key instrument (Sugiyono 2013). The reason for using this method is based on the need to get in-depth data to the school as the person in charge of wisata barokah activities carried out by SDIT ALIKHLAS.

This research was conducted at the home of the Principal of SDIT AL-IKHLAS located in Mantren Village, Karangrejo Subdistrict, Magetan Regency within one month. The data collection technique uses interviews and observations. The informant in this study was the principal of SDIT AL-IKHLAS. The phenomena in the study were analyzed using Max Weber's social action theory perspective. In his theory Weber explained that there are four types of actions, namely traditional action, affective action, instrumental rationality, and value rationality (Muhlis \& Norkholis, 2016). This theory is relevantly used to explain the phenomenon of "wisata barokah" which became the strategy of teachers in carrying out religious education in the pandemic period.

\section{RESULTS AND DISCUSSION}

\subsection{Planning "Wisata Barokah" At Sdit Al- Ikhlas}

Wisata Barokah is a new learning innovation applied by SDIT AL-IKHLAS in providing religious materials to learners during the pandemic. This activity stems from the teacher's desire to provide more effective teaching and easy to understand by learners, because based on the results of the evaluation of the teacher online learning that has been applied in the three months since the pandemic is considered less than optimal. As the theory explains that learning planning is the process of decision-making results thinking rationally about certain learning goals and objectives, namely behavioral changes and a series of activities that must be done as an effort to achieve goals by utilizing all the potential and sources of learning that exist. This planning should have objectives, strategies, supportive resources, and implementation in every decision (Sanjaya 2015).

Therefore, with the pandemic resulting in teaching and learning activities in educational institutions to be less than optimal, based on the results of interviews with the principal of SDIT AL-IKHLAS explained that the teachers in this school then held deliberations with various elements such as school committees, villages, and the surrounding environment to plan for effective new breakthroughs to overcome this problem. In the deliberations, the teachers provided an alternative new learning method called "wisata barokah" as a temporary replacement for distance learning activities that were then mutually agreed upon. The initial concept of wisata barokah activities itself is similar to outdoor learning. The students will be placed scattered in several mosques, and inside the mosque the students and teachers conduct face-to-face learning activities directly while adhering to health protocols. There are 10 mosques scattered in various villages in magetan regency that are used by the school in carrying out this activity. From this it is seen that the school really has a careful planning to carry out this activity. In addition to the goal to organize learning to be more effective, this activity also aims to bring students closer to the real environment and bring closer between the material and implementation in the field.

Strategies to achieve these goals have also been well established. The school has been trying to direct planning ranging from themes, RPPs and schedules that can support learning activities because of course there needs to be some new adjustments. All these things must 
support each other so that the purpose of this wisata barokah activity can be achieved. Another strategy that is applied is to strive for socialization to parents about this program so that "wisata barokah" activities can run optimally, in addition to socialization the school also seeks to build cooperation with external parties who are felt to be able to help the practice of this activity. In planning that includes syllabus and learning implementation plan (RPP) must indeed contain the identity of subjects, competency standards (SK), basic competencies (KD), indicators of competency achievement, teaching materials, learning objectives, learning methods, time allocation, assessment of learning outcomes, learning activities, and learning resources (Amri 2013).

Other supporting things to support learning activities have also been carried out by the school including debriefing to teachers related to education and training in order to have competence in teaching with this outdoor learning method as well as supporting facilities and infrastructure such as permits of places and activities in mosques to be occupied. The implementation of this policy also went well, all the policies decided to lead to the initial purpose of this wisata barokah activity, as explained by the principal that wisata barokah aims to provide religious material to students in a different way than usual as a result of the pandemic, with the aim of exploring creativity and ethical values because they are directly in the community environment. Learning activities do need to be centered on learners, able to develop the creativity of learners, create challenging and pleasant conditions, provide a pleasant learning experience, and charged with values, ethics, aesthetics, logic, and kinetics (Sanjaya 2015).

Based on an interview with one of the teachers of SDIT AL-IKHLAS also explained that from individual teachers have prepared this wisata barokah planning through the Learning Implementation Plan (RPP) and themes that are in accordance with the location and material. Based on the results of observations also the place chosen is in accordance with the theme that has been prepared by these teachers.

\subsection{Implementation Of "Wisata Barokah" At Sdit Al-Ikhlas}

Techniques of conducting wisata barokah similar to outdoor learning that is located outside the classroom turned out to be very effective in practice, the students became easier in understanding the material because they could interact directly with the teacher after a long time only interacting virtually, in addition the students also gained more knowledge because by holding learning in the mosque they could be more serious in learning the knowledge gained. A new learning experience in their current environment.

During the learning process, students are also very enthusiastic and active. Nature classes are indeed an ideal place, especially to do a learning process based on experience (Riskomar 2004). With a combination of a new environment and a different teaching and learning process than usual provides an opportunity for students to change behavior patterns and daily habits through a fun process. In technically the students scattered in various mosques are also given an evaluation that aims to find out how far the understanding of students in understanding the material described because indeed wisata barokah activities themselves are not initially mandatory, parents are allowed if they do not want their children to participate because this activity itself is initially still a trial and the implementation is also still in the fasting month. But after Eid and the school has entered the new school year, it turns out that the students who follow this wisata barokah activity are increasingly even reaching $90 \%$ of the principal's speech, so this makes the school again deliberating with parents to set new policies related to the learning model carried out in the future.

The result of the deliberation is to continue wisata barokah activities by changing some of the concepts, which distinguishes from the previous implementation of wisata barokah is that the activity is carried out in the school again because there are some parents who object if they have to deliver their children to mosques that are located far from home and also these activities are now routine so that students must enter on a rotating basis given the limitations of space. Schools should pay attention to health protocols.

In the running of this wisata barokah activity there are also some problems or obstacles that occur, including the first there is a spotlight from the Covid-19 task force of Magetan Regency because it conducts face-to-face learning activities directly, but from the school explained that they remain obedient to health protocols and what they do is not formal teaching and learning activities like school time usually, But activities are packaged into tours in which students can learn, play, and in general are not bound by school rules, lesson time is also flexible and students do not need to wear school uniforms. The second obstacle that had been faced was when looking for mosques that were planned to be used for activities wisata barokah there are some who refuse to be occupied on the grounds that there is no potential spread of the Covid-19 virus. This causes the school to have to look for other options so that it takes more energy and time. The third obstacle is that it takes readiness from teachers to adapt to new learning models, so that at first there are some teachers who are confused about what to convey in the material. 


\section{3. "Wisata Barokah" Reviewed From Max Weber's Social Action Theory Perspective}

Max Weber's social action theory is oriented towards the motives and goals of the perpetrator. With this theory it can be used to understand the behavior of each individual or group that everything has a motive and purpose on each action taken. By understanding this, we have appreciated their reasons for taking action. Weber reveals that the best way to understand different groups is to respect each other's form and type of action. So as to understand the reasons why the community acted (Saifuddin, 2015).

Max Weber classifies four types of social action: traditional action, affective action, instrumental rationality, and value rationality. The explanation of these types of actions is: First,traditional actions, are actions determined by habits that are already rooted in generations. Affective Action is an action determined by the condition and emotional orientation of the perpetrator. Instrumental rationality is an action aimed at the rational achievement of a particular goal. Value Rationality is an action based on values performed for certain reasons and purposes that have to do with values that are believed personally without taking into account the prospects that have to do with the success of the action (Bryan 2012).

So in an action carried out by each individual or group there must be a different orientation or motive of the goal. In the context of this research, the school in this case is SDIT AL-IKHLAS has certain reasons, motives, and goals to implement the policy of "wisata barokah" as a religious teaching strategy in the pandemic period. In this case study it can be understood through three typical theories of social action Max Weber, namely affective action, instrumental rationality, and rationality of values.

First, Affective Action, here we see how the conditions and situations of the pandemic faced make the school get a lot of complaints and input from parents of students because distance learning is burdensome for them for various reasons. With this phenomenon makes the school become emotional and depressed so that inevitably the school must respond to these complaints and inputs to create a new policy which is then called wisata barokah to accommodate the wishes of these parties.

Second, Instrumental Rationality, according to this theory explains how the SDIT AL-IKHLAS implements the wisata barokah policy can not be separated from the conscious thinking that they have the ability or capacity to carry it out. This means that to carry out wisata barokah activities, the school has thought about it consciously and rationally that they are indeed capable both in terms of human resources, their place, licensing, and other aspects that have an important role to serve as a basis for thinking that the policy can be implemented. So all parties agree that wisata barokah is the best solution to solve this problem.

Third, Value Rationality, according to this theory the actions taken are based on the values that can be taken by the perpetrator. In the sense of values in question are such as wisdom, benefits, and so forth when performing an action. In this context, the value or benefits of wisata barokah become an important measure that wants to be obtained by the perpetrators considering that the pandemic of teaching and learning activities becomes less effective if done remotely, so that with this wisata barokah innovation the school considers inevitably only with this policy the teaching and learning process in religious education can successfully run optimally.

\section{CONCLUSION}

Wisata barokah is a new learning innovation applied by SDIT AL-IKHLAS in providing religious education to learners in the midst of a pandemic. This activity is similar to outdoor learning so it provides benefits for learners because they gain new experiences by learning in a new environment. The existence of wisata barokah activities is also responded positively by parents, learners, and the surrounding environment for various reasons. Wisata barokah was initially carried out in several mosques in magetan regency, but after deliberation again with various parties, now this activity is carried out in the school environment. Although initially there were some obstacles that occurred but all of them can be overcome and now this school becomes the first elementary school in Magetan to hold face-toface learning activities directly since the pandemic. From the analysis of Max Weber's theory, the wisata barokah policy carried out by SDIT AL-IKHLAS has several motives in it, including affective action because it feels only this policy can be carried out because it can accommodate the wishes of all parties, instrumental rationality because rationally this policy is considered the most effective to run, and value rationality because the school believes only this policy will be able to succeed in the future. 


\section{REFERENCES}

[1] Amri, Sofan. 2013. Model Pengembangan \& Pembelajaran dalam Kurikulum 2013.

Jakarta: Pt. Prestasi Perpustakaan Kerja

[2] [1] A. Febriani and A. M Fauzi, "Efektivitas Kebijakan Daring Bagi Pendidikan Konseling Dalam Meningkatkan Mutu Peserta Didik Di SMAN 1 Mejayan," Suluh J. Bimbing. Dan Konseling, vol. 6, no. 2, pp. 1-10, Mar. 2021, doi: 10.33084/suluh.v6i2.2461.

[2] D. C. Y. Putri, "Perkuliahan Daring di Masa Pandemi Covid-19," J. PTK Dan Pendidik., vol. 6, no. 2, Jan. 2021, doi: 10.18592/ptk.v6i2.4151.

[3] N. Fadila, Nur Hariyati, "Implementasi Pembelajaran Luar Kelas (Outdoor Learning) Di Sekolah Kreatif Sd Muhammadiyah 16 Surabaya," Inspirasi Manaj. Pendidik., vol. 7, no. 1, 2019.

[4] A. Murfi, I. Fathurrochman, A. Atika, and N. Saiva Jannana, "Kepemimpinan Sekolah dalam Situasi Krisis Covid-19 di Indonesia," Manag. J. Manaj. Pendidik. Islam, vol. 5, no. 1, pp. 119136, 2020, doi: 10.14421/manageria.2020.51-07.

[5] A. Purwanto, "Studi Eksploratif Dampak Pandemi COVID-19 Terhadap Proses Pembelajaran Online di Sekolah Dasar," J. Educ. Psychol. Couns., vol. 15, no. 2, pp. 98-112, 2019.

[6] T. Z. Y. Wardhani and H. Krisnani,

"Optimalisasi Peran Pengawasan Orang Tua Dalam Pelaksanaan Sekolah Online Di Masa Pandemi Covid-19," Pros. Penelit. Dan Pengabdi. Kpd. Masy., vol. 7, no. 1, p. 48, 2020, doi: 10.24198/jppm.v7i1.28256.

[7] A. Muhlis and N. Norkholis, "Analisis Tindakan Sosial Max Weber dalam Tradisi Pembacaan Kitab Mukhtashar Al-Bukhari (Studi Living Hadis)," J. Living Hadis, vol. 1, no. 2, p. 242, 2016, doi: 10.14421/livinghadis.2016.1121. 